\title{
Research on the Function of Film and Television Music in Music Appreciation Class
}

\author{
Yong Zhou \\ Art Institute, Yulin University, Yulin, Shaanxi, China \\ 317950860@qq.com
}

\begin{abstract}
Keywords: Music education; Music appreciation; Music accomplishment; Aesthetic ability; Music quality development
\end{abstract}

\begin{abstract}
Music appreciation class in higher music education music quality development course, through different periods, different styles of music and musicians of listening, so that students develop thinking on the mastery of basic theoretical knowledge and basic techniques play on, to enhance the students' music accomplishment, form a good artistic feelings, create a good the aesthetic ability and lay a good foundation. The cultivation of students' appreciation ability is an important part of music education and teaching. It is also the basis for students to improve their professional accomplishment and aesthetic ability. The course of music appreciation is a platform for students to expand their musical quality.
\end{abstract}

\section{Introduction}

The movie, also known as the pictures. It is a modern art developed by the combination of motion photography and slide projector. It is a kind of art characterized by art including literature, drama, photography, painting, music, dance, writing, sculpture, architecture and so on. It has a comprehensive art surpassing other art categories. With its unique artistic charm, film has gradually become one of the most popular art categories. A good movie, not only contains a good script, the story, the advanced photography method, an angry eye popping special effects, according to the plot of the movie development and the creation of music, but also an important part of the art of film. $[1,2,3]$ Film music and film footage of the organic combination of the formation of film music unique charm - interactive picture. Let the students experience the charm of film music, and learn to analyze the difference between listening and appreciation of film music and film and comparison of different interaction, should also become one of the important contents in the course of music appreciation. [4,5,6,7]

\section{Present Situation Analysis and Existing Problems}

First of all, the teaching purpose and content of music appreciation course and the teaching methods should be kept pace with the times and should provide students with a wide range of appreciation. However, due to the restrictions of curriculum, class hours and data, the content of music listening course is relatively single, and the content of listening and explaining is confined to the music works of famous musicians in different periods in the west. Second, for the film music listening almost no interactive pictures for the movie appreciation, just watching the level has not become the music appreciation lesson. $[8,9,10]$

In ensuring the normal music teaching schedule and order, the appreciation of film music into the classroom, how to cultivate and improve the students' diversified aesthetic thinking ability through them, become music lesson purpose. With modern teaching methods to help students contact foreign film art master works of masters work analysis, to enable students to gradually learn to experience, from different movie picture interactive embodied in artistic charm. Let students gradually learn to analyze movies, music, creative techniques, styles, and enrich their appreciation. 


\section{The Principle of Introducing Film and Television Music}

Aesthetic Principle. Aesthetic education is the core part of music education in primary and secondary schools, that is, aesthetic education, that is, aesthetic education, is to train people's aesthetic ability and aesthetic sentiment education. It takes the perfection of personality as the ultimate goal, and takes artistic and realistic beauty as the means of education. To cultivate students' love for good music, to help them set up the correct aesthetic concept, to develop healthy and upward aesthetic appeal, and to enlighten the wisdom, purify the mind and edify the sentiment. The nature and value of music curriculum is mainly reflected in the aesthetic value, creative development value, social value, cultural value, embodies the aesthetic experience as the core, make learning interesting, rich and colorful, with a clear sense of the times and nationality, guide the students to actively participate in the music practice, respect for different music students the individual experience and learning ways to improve students' aesthetic ability, develop students' creative thinking, forming good humanistic quality, lay a good foundation to enjoy music for students life-long love of music, learning music.

Principle of Validity of Questioning. Each of the students' questions, should be effective link a teacher design, have a choice, is a process of "swing all sand only see the gold, different problems, different levels of students in difficulty right arrangement, in order to maximize the effectiveness and quality of classroom questioning. Classroom questioning must be accurate, according to the student's "recent developments", aimed at "bull's eye", can not be too vague and general. For example, when appreciating the song "in vain", the teacher can not just ask, "what is the style of this piece of music?"" The term "style" is too large, a time of students ignorant, students will lead to ice stuck, unable to achieve the purpose of questioning, it is difficult to form the strength of thinking. Therefore, the content and method of design should be detailed and targeted.

Flexibility Principle. Teaching is an art, teaching methods are varied, and they permeate each other and complement each other. With the help of film and television music, we should grasp the principle of flexible line. The music class is not the task of training a special music talent, but for all students, with students as the main body, to improve every student's music accomplishment, make every student's music potential to obtain the development, and enable them to benefit from.

\section{Methods}

Using multimedia teaching to analyze the works of movie master. With the rapid development of information technology and the deepening of quality education, the new curriculum reform, put forward a series of new teaching ideas of curriculum reform of basic education, teachers should actively realize the transformation and development of their own, in order to keep up with the pace of development of music education in the twenty-first Century. The classroom teachers should break the traditional teaching idea is the center of knowledge, teachers are the center of the "two centers" to break the habit, teacher centered and textbook centered teaching mode; teachers change from pure knowledge for the organizers of teaching activities, students explore knowledge guide and collaborators the selection of teaching content; the more close contact with the social reality and the actual life of students; students learn more autonomy, cooperation and explore the relationship between teachers and students; harmonious, democratic and equal. Pay attention to the law of students' psychological development and the need of study, so as to take the development of students as the center". Teachers, do the new music teacher, music in the new curriculum "learning guide and facilitator" and "students' cooperation and exchange", "teaching researchers and designers, curriculum developers and builders". In the teaching process, students become the protagonist, is always the subject of learning; teachers should change the "Teacher centered" and "teaching center" of the traditional concept, implementation of democracy, equality, harmonious relationship between teachers and students; teaching relations, multilateral interaction, cannot What I say goes. "or" full hall fill". In improving the students centered teaching skills, teachers should strengthen the service consciousness and moral construction, "all for students, for all students, respect for each student, 
care for each student. Promoting multilateral activities and multilateral interaction in teaching, changing the emphasis on accepting learning, rote learning and mechanical training.

The use of classroom discussion, analysis of different masters and interactive content, give full play to the imagination, expand students' thinking mode. The main purpose of music appreciation course in addition to the outstanding music appreciation of students at all times and in all countries outside, but also let students understand some musical knowledge, such as "a variety of Chinese and foreign musical instrument independent knowledge system and the classification of instruments and singing form etc.. Teachers in the teaching of the knowledge, let the students more often than listening to music is boring and monotonous, the students of these knowledge is not only not good grasp, and the study enthusiasm is not high, if teachers can use video music teaching, can greatly improve the students' interest in learning, and make the abstract knowledge become vivid and intuitive. Students are easy to understand and accept. Therefore, in the future music teaching, we should vigorously strengthen the use of film and television music to help students understand the function of common sense of music, rather than just the film and television music as a powerful helper in music appreciation class". For example, in the teaching of symphonic knowledge, the author shows the pictures in each instrument are arranged in groups on the big screen, on the edge of knowledge points, click on the corresponding edge instruments have the picture, because the musical film music video inserted here, so immediately received audio-visual effects, grasp the students' ears and eyes, to arouse students learning interest and desire.

\section{Conclusion}

This project is based on the Art Department of current teaching situation, the problems of music majors in the teaching process are summarized, existing in the practice teaching is not perfect place to carry on the analysis, the combination of theory and practice. How to upgrade and expand the music appreciation ability and aesthetic ability of the students majoring in art education is the core of teaching music appreciation class, students will form a diversified and multi-level aesthetic framework is an important content of music appreciation course. In the practical teaching process, through the case to explain, classroom teaching methods, teachers and students gradually formed a mutual promotion and common development, make guidance to the practice of scientific research, scientific research and theoretical support for the practice of teaching, and continuously expand the music majors in music appreciation model put forward new development direction for students, give practical help for the teaching reform of deep in the future.

\section{References}

[1] High school music appreciation teaching in popular music [J]. Zhang Yun. Art (Journal of Shanxi Academy of Arts) 2013 (01). (in Chinese)

[2] A preliminary study of the teaching methods of Western classical music appreciation in [2] high school music [J]. Zhang Chang. New curriculum (next). 2016 (10). (in Chinese)

[3] High school music appreciation teaching of [J]. Luo Qiao. (a) science educ. 2011 (10). (in Chinese)

[4] Emotion experience in music appreciation in senior high school teaching in the infiltration of [J]. Luo Qiao. (a) science educ. 2011 (11). (in Chinese)

[5] High school music appreciation class in the development of multi part music aesthetic ability [J]. Wu Jing. Northern music. 2014 (05) .(in Chinese)

[6] S effective strategy of "living" in high school music appreciation class [J]. Deng Ming. Music grand view. 2014 (02). (in Chinese)

[7] High school music appreciation (appreciation) teaching drawbacks of [J]. Xu Qianzi. Journal of Liaoning Academy of education. 2009 (08). (in Chinese)

[8] High school music appreciation teaching how to promote students' emotional experience of Zhang Mingde [J].. (a) science educ. 2008 (07). (in Chinese) 
[9] To develop interest in learning is the high school music appreciation teaching guide [J]. Hong Yao. Journal of Nanchang Education College 2006 (02). (in Chinese)

[10] High school music appreciation is the emotional experience of [J]. Wu Taotao. Consumer guide. 2006 (10) (in Chinese) 